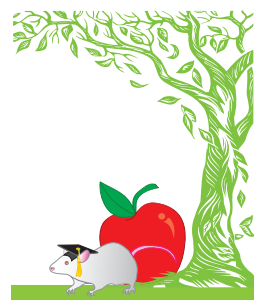

\title{
Vendors assisting in training programs, part 1
}

Mark your calendars for the upcoming LAWTE-CALAS meeting on training and welfare in Winnipeg, Canada, on 4-7 May 2013 (http://www.lawte.org/ and http:// calas-acsal.org/symposium/).

The tree icon representing the Fruits of Education column has many branches. Just as branches support the great canopy of a tree for its animal occupants, vendors support laboratory animal facilities and their inhabitants. Their outstretched branches provide protection (caging), sustenance (feed) and various products (biological agents). Thus, the notion of vendor branches providing training is worthy and will serve as the focus for a couple of columns.

Sometimes overlooked as 'fruit' on the tree are the resources for training programs provided by the purveyors of equipment and services for our facilities. But their expertise, product literature and experiences can bring multitudes of benefits. As a trainer, I have been appreciative of the various 'training branch' resources that some companies offer.
These tools make my job easier and facilitate the best care for animals.

First, vendors can offer information. This can include informational websites; images that can be used in presentations (with appropriate acknowledgment); product research and development literature; related details such as 'white' or position papers; and literature searches from academic publications. Most vendors can provide handouts with product literature or downloadable documents on equipment safety, maintenance and repair from which passages can be quoted in training materials. Vendors may also offer background and historical information that can help students to explore the evolution of lab animal science. Finally, company newsletters may include articles that describe the use of products in greater depth, including specific applications.

Second, vendors can provide active training. Many companies have technical representatives who conduct facility inservice' training, who attend and present at local AALAS meetings or who give presentations in training courses (e.g., AALAS certification classes). Active training can also include sponsored webinars.

Finally, vendors may also donate equipment to be used in classroom demonstrations for training purposes.

Many of these training resources are available free of cost, although some may carry a small fee. Trainers should keep in mind the time and effort that would be spent in compiling the same amount of information and materials themselves to assess the potential for savings. There are companies whose business it is to develop training curricula for us - turnkey solutions that may be appealing to the over-worked facility manager or institutional trainer.

Here I provide an initial listing of organizations having corporate training objectives with whom I've had some dealings (Table 1). I know there are more 'branches', so please share. I will include them in future columns so that readers can go 'picking'.

\begin{tabular}{|c|c|c|}
\hline Organization & URL & Contact \\
\hline Laboratory Animal Welfare Training Exchange & http://www.lawte.org/ & $\begin{array}{l}\text { Bruce W. Kennedy } \\
\text { bkennedy@csupomona.edu }\end{array}$ \\
\hline Tecniplast USA & $\begin{array}{l}\text { http://www.tecniplast.it/education/ } \\
\text { training-initiatives/ }\end{array}$ & $\begin{array}{l}\text { Paulina Michaud } \\
\text { pmichaud@tecniplastusa.com }\end{array}$ \\
\hline Veterinary Bioscience Institute & http://www.vetbiotech.com/ & $\begin{array}{l}\text { Ann Sproul } \\
\text { annsproul@vetbiotech.com }\end{array}$ \\
\hline American Association for Laboratory Animal Science & http://www.aalas.org/ & $\begin{array}{l}\text { Nicole Duffee } \\
\text { nicole.duffee@aalas.org }\end{array}$ \\
\hline Animal Care Training Services & http://actstraining.com/ & $\begin{array}{l}\text { Paula Clifford and William Singleton } \\
\text { info@actstraining.com }\end{array}$ \\
\hline Behavioral-Based Biosafety Training Programs & http://www.seankaufman.com/ & $\begin{array}{l}\text { Sean Kaufman } \\
\text { sean@seankaufman.com }\end{array}$ \\
\hline MIP/Anesthesia Technologies & http://www.mipcompany.com/ & $\begin{array}{l}\text { Jim Houts } \\
\text { info@mipcompany.com }\end{array}$ \\
\hline $\mathrm{ClearH}_{2} \mathrm{O}$ & http://www.clearh2o.com/ & $\begin{array}{l}\text { Laura Lockwood } \\
\text { llockwood@clearh2o.com }\end{array}$ \\
\hline
\end{tabular}

